\title{
MALAQBIQ LOCAL VALUE IN EFL WRITING CLASS
}

\author{
Rabiatul Adawiah ${ }^{1}$, Prisna Aswarita Putri ${ }^{2}$ \\ Sekolah Tinggi Agama Islam Negeri Majene ${ }^{1}$, Institut Agama Islam Negeri Palu ${ }^{2}$, \\ South Sulawesi, Indonesia \\ rabiatuladawiah@stainmajene.ac.id ${ }^{l}$,prisna_aswaritaputri@iainpalu.ac.id ${ }^{2}$
}

\begin{abstract}
The purpose of this study is to integrate malaqbiq local value, Islamic values, and language skill in the Writing in General Communication course. It was conducted at the English Education study program of STAIN Majene in 2019 by employing a descriptive qualitative research method with a total of 32 participants. Data gathered from interview, field notes, questionnaire, and RPS document analysis showed that the process of implementing malaqbiq value which included planning, implementation, and evaluation of learning had not encountered such a big obstacle because it has been supported by vision-mission of STAIN Majene which exemplify the value per se and the learning achievements of KKNI curriculum which contains affective aspect. Indicators of malaqbiq value related to writing skill are having a broad and advanced view in writing; creating introductory paragraphs/statements containing greetings; choosing appropriate diction according to context; composing words appropriately according to grammar; using the proper spelling of words; writing correct information; writing with a sense of relief (based on personal judgement); writing with authenticity and one own's ideas (no plagiarism); writing with regards to context (who and where), and writing text according to rules.
\end{abstract}

Keywords: Malaqbiq; Mandarese; Writing Skill.

\begin{abstract}
ABSTRAK
Malaqbiq adalah nilai lokal yang dianut oleh masyarakat suku Mandar sebagai sumber pembangunan karakter. Tujuan penelitian ini adalah mengintegrasikan nilai malaqbiq, nilai Islam dan keterampilan Bahasa dalam mata kuliah Writing for General Communication. Penelitian ini dilaksanakan pada program studi Tadris Bahasa Inggris STAIN Majene tahun 2019 dengan menggunakan metode penelitian kualitatif deskriptif pada dengan 32 partisipan. Data yang dikumpulkan dari wawancara, observasi, angket, dan analisis dokumen RPS menunjukkan bahwa proses implementasi nilai malaqbiq pada tahap perencanaan, pembelajaran dan evaluasi tidak mengalami kendala karena didukung oleh visi dan misi STAIN Majene yang bermuatan malaqbiq, serta capaian pembelajaran kurikulum KKNI yang meтuat aspek sikap. Indikator nilai malaqbiq yang terkait dengan pengetahuan keterampilan menulis adalah memiliki pandangan yang luas dan maju dalam menulis; membuat introductory paragraph/statements yang memuat salam, sapaan atau bentuk perkenalan; memilih diksi yang tepat sesuai dengan konteks; menyusun kata dengan tepat sesuai dengan tatabahasa; menggunakan pengejaan kata dengan tepat; menulis informasi yang benar; menulis dengan perasaan lega (berdasarkan penilaian pribadi); menulis dengan gaya dan ide sendiri (tidak plagiat); menulis dengan memperhatikan konteks (siapa dan dimana); dan menulis teks sesuai dengan aturan.
\end{abstract}

Keywords: Malaqbiq; Mandar; Kemampuan Menulis.

\section{INTRODUCTION}

Writing is one process of human communication using symbols and readable form. Some scholars argued that it is the most difficult skill compared to others such as reading, 
listening and speaking (Watcharapunyawong \& Usaha, 2013). Writing is a productive skill that needs creativity in presenting ideas; moreover, the written form shows the complexity of lexical, syntactic, and semantic knowledge. It is quite acceptable when one mistakenly pronounces words in speaking. But if one happens to mistakenly spell words in writing, especially in an academic context, that will be unacceptable. Writing activities,

The globalization era forces societies to have an appropriate writing skill. Writing also becomes crucial in academic life since publication in indexed journals is one of the mandatory duties for the scholar to hold a certain academic position. Publishing articles as research output can be seen as an effort to share knowledge and information. The more articles produced by scholars in a country, the wider knowledge in that country is. It implies that writing can be an indicator to see the development of a country.

Indonesian students start to acquire writing as one language skill in elementary schools. Firstly, they learn alphabet letters and then do some practices of writing even though it is still in recall activity. Elementary students are shown sample sentences, and they are asked to rewrite them. That writing tasks will continue until the third grade of elementary schools. In the next grade, students will use writing skills in doing exercise. In junior high school, the students begin to build creative writing using simple topics. These activities involve literary works such as poems and short stories. It is quite similar to writing tasks in senior high school. Last, university students will learn some challenging activities of writing namely academic writing to produce articles and thesis.

According to the Indonesian National Framework Curriculum (KKNI), one university students' responsibility is to publish their final project or thesis (Imroatus, 2016). This is challenging for students because they are not equipped with adequate knowledge to thrive ton his task in their early language learning process. This task is whole different level than any other tasks they survived before. It will be more complicated if the students are asked to conduct research and write a thesis using foreign languages. This reality is faced by students of English and Arabic departments, especially when their first language interferes.

That policy which is not supported by the readiness of students consequently forces them to plagiarize any sources when they have a writing task. Plagiarism is frequently conceived as misleading behaviour that breaks writer's copyright; taking text or ideas without the proper way of citing (Fatimah \& Wulandari, 2018). The most common form of plagiarism committed by the students is to copy-paste online resource text from internet without stating the source. It cannot be denied that the students commit plagiarism unintentionally. With lack of knowing, they are unaware that their action is unethical. The students are not taught how to quote, paraphrase, cite and manage references (Bahadori M \& Hosein M, 2012). Shortly, the students lack knowledge about level of plagiarism, so this issue should be introduced earlier to create and maintain a positive writing habit.

Teachers' and students' attitude toward academic writing also become another factor which contributes to the aforementioned issue. For students, plagiarism is seen as more practical and efficient. Meanwhile, teachers have little time to read their students' papers thorough Easy accesses on the internet in contrast to access to Turnitin gives ample opportunities to commit plagiarism. In unconducive academic culture, plagiarism becomes a usual act in writing practice. It means that, besides knowledge, t positive attitude, character, and awareness toward this issue. A positive academic culture should be established so teachers and students are able to appreciate every work and avoid plagiarism (Bahadori M \& 
Hoseinpourfard M, 2012).

In order to solve the aforementioned issue, establishing an applicable positive academic culture needs to be immediately done. One way to achieve that goal is by integrating local culture in the learning process. Malaqbiq is one value of Mandarese; local ethnic in West Sulawesi province, that integrates local and Islamic values. This value covers all aspects of Mandarese people's life, including the language use. The effort of integrating local values the in learning process is proven to significantly contribute in the students' character building. Based those arguments, the researchers are convinced that Malaqbiq as a local value can be integrated in writing class at the university level to overcome plagiarism issue.

\section{LITERATURE REVIEW}

\section{Malaqbiq as Local Value of West Sulawesi}

Malaqbiq is a prominent word in West Sulawesi province. This province exemplifies the spirit of this word through its government officials' work culture. Politicians in this province also use this word as their political jargon as sales material that can reach many voters. Unfortunately, the use of such local word is not equipped with a complete and valid concept. This is due to the lack of records regarding conceptual definition, especially those from ancient sources or literature such as the lontaraq manuscript or other forms.

This lack of information has led to many interpretations of the word malaqbiq by various parties. The first issue is related to the root word of malaqbiq. Some people assume that the root word of malaqbiq is laqbi which means more or over (laqbi barena Andi $=$ Andi gets more portion (than others)). This assumption is based on the description of to malaqbiq which is literally translated as those who have more merits than people in general. The meaning then pragmatically transforms into a person of merit or a prominent person. But other people are convinced that malaqbiq is a root word without an affix. This opinion is based on the notion that word laqbi (more) and laqbiq in the word malaqbiq are totally different, though essentially the two opinions still refer to the same meaning (Idham \& Saprillah, 2013).

The second issue to discuss is the position of incessant use of the word malaqbiq as a group or social identity. Initially, malaqbiq was a tribute to someone who was considered to have a good human nature such as educators, scholars and local community elites; or in other words, it is a personal identity. The Mandar community did not know a term "malaqbiq village" either. However, along with the need to build a prominent image of West Sulawesi province when it was formed in 2004, its figures chose the word malaqbiq to exemplify the virtue. Furthermore, the word is used intensively in government activities, institutions and political agenda. The nature of malaqbiq in general can be divided into two, namely malaqbiq lao in Puang and malaqbiq lao di rupa tau, or in Islamic terms habluminallah and habluminannas. Malaqbiq lao in Puang means maintaining a relationship with God Almighty by believing and being devoted (carrying out Allah's orders and staying away from his prohibitions. Furthermore, malaqbiq lao di rupa tau has the meaning of maintaining good relations among humans such as respecting fellow human beings and appreciating each other. There is also the concept of the malaqbiq trilogy as a standard or measure consisting of malaqbiq pau, malaqbiq kedo and malaqbiq gauq (Rahman, 1988). 


\section{RESEARCH METHOD}

This study uses a qualitative research design that emphasizes the description of the continuity of the character education implementation in terms of both the RPS design and the implementation of learning for the Writing for General Communication course. Silver argues that evaluation research is used by considering the effectiveness of old and new programs, and the steps in creating some results or changes. This research was conducted in class TI.1 and TI.2, the third semester, English Education study program of STAIN Majene with a total number of 32 participants.

Instruments used in this research were analysis sheets of RPS documents, research rubrics, questionnaire, field notes, interview, and students' learning outcomes in the Writing for General Communication course. Data of this research were collected through several procedures, namely (1) collecting literature and teaching materials; (2) carrying out a Focus Group Discussion with speakers, lecturers and students of the English Education study program regarding the integration of malaqbiq and learning outcomes that should be targeted in the Writing for General Communication class; (3) conducting a follow-up interview as a form of confirmation and consultation with Dr. Sri Musdikawati, M.Si, Drs. Subriadi Bakri, MM. and As'ad, M.Pd.I as experts and practitioners of learning the value of Mandar local wisdom; (4) designing RPS, assessment rubrics and teaching materials in the form of PowerPoint; (5) carrying out the learning process as well as observation; and (6) distributing questionnaires as a form of evaluation.

Data analysis was carried out in a descriptive qualitative manner and through several steps. They were (1) data collection, (2) data reduction, as a process of selecting, focusing, and transforming rough data, (3) data presentation, including descriptions of data extract exposure, and (4) conclusion drawing, where the researchers concluded and found an answer to the addressed problem formulation by considering the results of the instrument and process during the research and linking them with related theories which were used as references.

\section{FINDINGS AND DISCUSSION}

\section{Findings}

\section{Interconnection of Malaqbiq Values and KKNI-based English Curriculum Aspects}

Scientific integration between local wisdom and foreign language learning did not find any significant obstacles. This was possible because the values upheld in Mandar culture including malaqbiq did not conflict with universal values embraced by the global community. Likewise, the integration of malaqbiq and Islamic values was not a significant obstacle either. This was possible because Mandarese people also rely on Islamic sharia as mentioned in Mandar texts.

Writing for General Communication is a course that hones students' writing skills for general communication purposes, especially daily communication related to student academic activities. To achieve this goal, the researchers first prepared lesson plan which contained subject identities, learning outcomes, materials, methods, and duration and reference sources in learning. In the planning process, they have also compiled indicators of malaqbiq value through a library study and adjusted it to the learning outcomes of this course. Below are the indicators and their codes: 


\begin{tabular}{|l|l|}
\hline No. & \multicolumn{1}{|c|}{ Indicators of Implementing Malaqbiq values in Learning } \\
\hline 01 & Praying before study \\
\hline 02 & Reciting short surah before study \\
\hline 03 & Showing tolerance and appreciate each other \\
\hline 04 & Being open minded to explore ideas \\
\hline 05 & Showing well-mannered behaviour \\
\hline 06 & Having strong intention to follow learning process \\
\hline 07 & Committing to follow learning contract \\
\hline 08 & Holding commitment to study well \\
\hline 09 & Being independent and have motivation \\
\hline 10 & Writing introductory paragraph/statements consisting greeting and \\
\hline 11 & introduction \\
\hline 12 & Arranging words based on grammar \\
\hline 13 & Using correct spelling \\
\hline 14 & Writing correct information \\
\hline 15 & Writing based on experience and personal perception \\
\hline 16 & Being honest and do not plagiarize \\
\hline 17 & Considering the situation and context in writing \\
\hline 18 & Writing text following the rules \\
\hline
\end{tabular}

\section{Processes of Implementing Malaqbiq Values in Writing Class}

After a series of lesson plan was completed, the researchers then carried out the learning process in the classroom. At the first meeting, the lecturers and students agreed on several lecture contracts related to general rules and regulations that implemented the malaqbiq value. Rules and regulations listed on the lecture contracts were: minimum attendance limit of $80 \%$, a maximum delay of 10 minutes, to read a prayer and short surah before studying, dress neatly and show a clear face when studying, sit according to gender groups and value and respect others. All regulations were implemented with full commitment to the lecture contract and academic rules regulated by STAIN Majene. The following picture was taken when students read a prayer and a short surah:
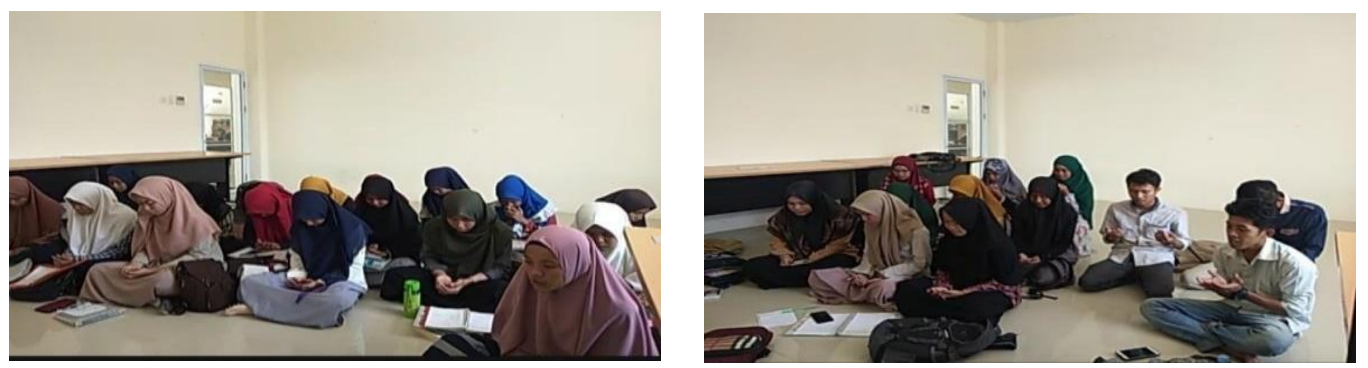

Researchers as the lecturers in the Writing for General Communication course also allowed students to introduce themselves to better know their identity especially about their ethnic or ethnic background, as well as their motivation in learning. They found that students had inadequate knowledge regarding writing skills but had great motivation to study and 
aware that it is their responsibility as students of the English Education study program. Unfortunately, writing was degradedly perceived as a mere activity to write down what they saw or heard, even though as university students, they should perceive writing as a form of creativity or commonly referred to as creative writing. Below were pictures of the implementation of the introduction:
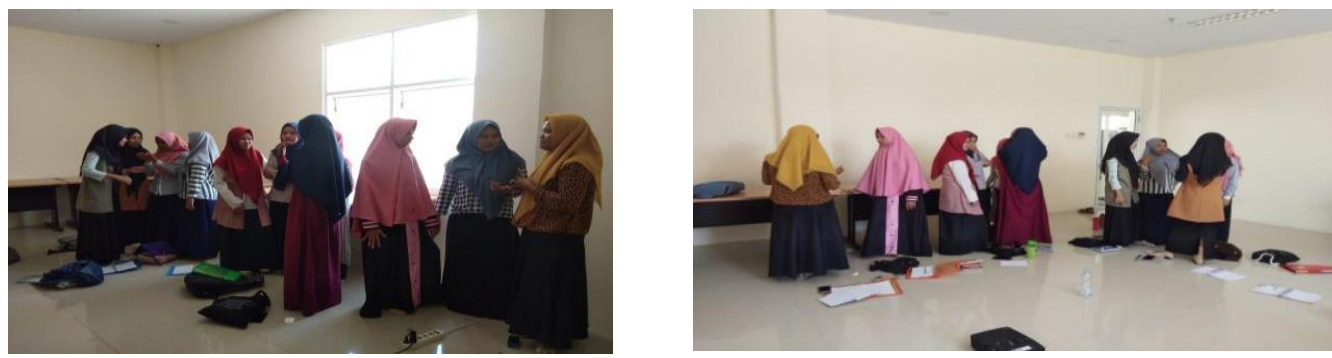

The introduction was carried out with corner games in anticipation of big class. Students were given several statements, then directed to determine a YES / AGREE or NO / DISAGREE attitude. The YES group stood on the right side, while the NO group stood on the left side. After that, students were directed to discuss and share information about their opinions. Finally, they were invited to express their respective views and were directed to respect each other's opinions.

At the second meeting, students were introduced to the definitions, goals, tips and values a good writer must hold. In addition, students were also taught about the issue of plagiarism which has become a trending topic among academics. This issue was related to several descriptions of the value of malaqbiq, especially to marrappa atonang or not taking the rights of others. In this case, students were directed not to copy and paste when writing their paper assignments, and also not to cheat for independent assignments. By doing so, students could uphold the universal value; honesty in their writing activities. Students were taught to build their original ideas with mind mapping activities. The following was an example of a mind mapping created by students. This picture showed that one topic such as hobbies might lead to many different answers.



At this meeting, students were taught about the concept of malaqbiq, the classification of malaqbiq (talk, attitude and behave) and their relation to the concept of mapia. In other words, the value of malaqbiq was used as learning material. All indicators of malaqbiq value related to skills were discussed at this meeting, then internalized and used 
when students write in the next meeting. Researchers chose several topics which were considered relevant to the communication that students usually do regarding academic activities. The topics were hobbies, daily activities, messages to lecturers and some writings that would be posted on social media.

The values of malaqbiq which were implemented in subject assignments as part of the form of knowledge and skills attainment were (1) possessing a broad and advanced perspective in writing; (2) making introductory paragraph/statements containing greetings, greetings or forms of introduction; (3) choosing the right diction according to the context; (4) arranging words appropriately according to grammar; (5) using the correct spelling of words; (6) writing correct information; (7) writing with relief (based on personal judgment); (8) not adapting part / all of other people's writings (plagiarism); (9) writing with attention to context (who and where); and (10) writing text according to the rules.

Meanwhile, malaqbiq values which could be linked to positive attitudes in each meeting were (1) reading prayer before studying; (2) reading a short surah before studying; (3) showing tolerance and mutual respect; (4) showing a polite and polite attitude; (5) possessing a good and strong intention to follow the lesson; 6) following lecture contract and the agreed academic rules; 7) committing to learning; and (8) possessing independence and willingness or motivation to learn.

\section{The Implication of Integrating Malaqbiq Values in English Writing Class}

The form of learning evaluation used in this study was an assessment of students' writing during their mid-term test and the results of questionnaires about the students' knowledge and perceptions of the implementation of the malaqbiq value in the Writing for General Communication class. Both forms of evaluation were carried out in order to complement the data in this section.

At the eighth meeting, students were given a Mid-term test in the form of a writing assignment with the theme "Eating Habits". The mid-test was conducted outside the classroom, namely Rewata'a Mangrove Park which is located not far from STAIN Majene campus. Providing a relaxing learning atmosphere by setting an outdoor class with a beach view showed an effort to create a sense of relief when writing, in which the researchers implemented the description of malaqbiq, namely to tammasuang kedo (people who are not rigid in acting), mapia pengawa (relieved in doing) and mapia peita (broad view). Researchers also took a chance to conduct a test in the form of on the spot writing. Students were led to write at least 200 words in 60 minutes including making a mind mapping. The following pictures are an overview of the learning atmosphere: 

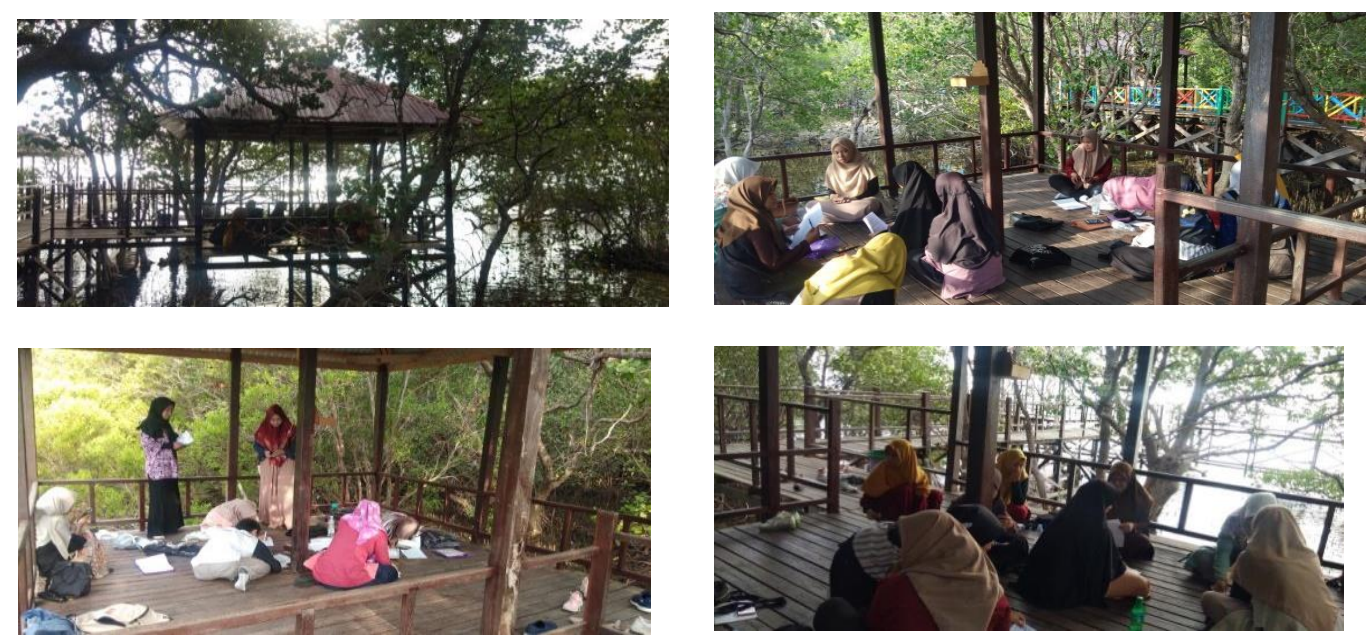

The results of the writing proved that students had shown excellent honesty values in carrying out writing task. Researchers who also acted as lecturers did not supervise students. They were left to discuss and chose the most comfortable place to write. And the result showed no student had the same writings. Even though they had the same breakfast habits, even their breakfast routines are carried out together, but they expressed it in their respective language style. The mean score of student papers from a total of 32 students was 82.81 with a per-item score/assessment aspect as follows:

\begin{tabular}{|c|l|c|}
\hline No & \multicolumn{1}{|c|}{ Assessment Aspect } & Score \\
\hline 1 & Originality & 98,75 \\
\hline 2 & Following the Theme & 87,5 \\
\hline 3 & Following the systematic: number of words and orderly & 73,75 \\
\hline 4 & Ordering the paragraphs & 76,25 \\
\hline 5 & Consisting clear main ideas & 76,87 \\
\hline 6 & Using correct grammar & 71,87 \\
\hline 7 & Choosing the correct diction & 71,25 \\
\hline 8 & Rightness & 99,37 \\
\hline 9 & Using language level based on context & 74,37 \\
\hline 10 & Punctuality & 98,12 \\
\hline \multicolumn{2}{|c|}{ Total } & $\mathbf{8 2 8 . 1}$ \\
\hline \multicolumn{2}{|c|}{ Mean score } \\
\hline
\end{tabular}

The table above shows that the students had shown excellent writing skills, with an average of 82.81. Of the ten aspects of the assessment, there were three aspects that almost reach a perfect score, namely the correctness of the information, writing reflects personal work and on time. This shows that students were building a positive attitude in doing assignments. Other aspects still need to be improved, especially in the use of grammar and word selection which is still at a score of approximately 71. This grammar strengthening can be improved through several other courses. Whereas systematic writing has shown an increase, which was at a value of 73 to 76 . Most students had made an introductory paragraph followed by several explanatory paragraphs, and ended with a closing paragraph. 
The next form of evaluation was to spread out questionnaires to find out students' perceptions of the implementation of malaqbiq values and students' knowledge of malaqbiq values related to writing skills. The results showed that students had a very good or agreeable perception of the implementation of the malaqbiq value in writing classes. The average perception score of a total of 32 students was 94.74 or was in the strongly agree category. The following table is a description of the results of the questionnaire based on the type of question:

\begin{tabular}{|c|l|c|c|}
\hline No & \multicolumn{1}{|c|}{ Statements } & Score & Conversion \\
\hline 1 & Need to have praying before study & 127 & 99.22 \\
\hline 2 & Need to pray and recite short surah before study & 125 & 97.65 \\
\hline 3 & Construct a conducive learning situation & 119 & 92.97 \\
\hline 4 & $\begin{array}{l}\text { Malaqbiq values can avoid the writer from } \\
\text { plagiarism }\end{array}$ & 118 & 92.19 \\
\hline 5 & This subject describes Malaqbiq in writing skill & 110 & 85.94 \\
\hline 6 & $\begin{array}{l}\text { Malaqbiq } \text { related to Writing for General } \\
\text { Communication subject }\end{array}$ & 112 & 87.5 \\
\hline 7 & $\begin{array}{l}\text { Malaqbiq can change the students' character to be } \\
\text { responsible students }\end{array}$ & 120 & 93.75 \\
\hline \multicolumn{2}{|c|}{ Total } & $\mathbf{6 4 9 . 2 2}$ \\
\hline \multicolumn{2}{|c|}{ Average } \\
\hline
\end{tabular}

\section{Discussion}

The implementation of local values in foreign language learning such as English certainly has challenges. This is due to the combination of two very different values. Learning a foreign language such as English cannot be separated from the introduction of the values of English per se (Ali, et.al, 2016). One way that can be taken to integrate these two aspects is by looking for common and universal values. This research's results showed that the integration of malaqbiq local value and Islamic value in language learning could be developed. In general, the results showed that the integration efforts in this research did not experience significant obstacles. The first support is that the concept of malaqbiq has become the spirit of STAIN Majene's vision mission. Therefore, the implementation of malaqbiq value in the Writing for General Communication course is an activity for the purposes of study program development. In addition, this research can also be used as an effort to solve social problems such as the lack of knowledge of students about the local values (Birowo, 2015). The purpose of learning development is as a form of preparation in various learning situations, improving the motivation of teachers and learners and as a form of renewal of previous learning (Sari \& Setiawan, 2018). The results showed that the creation of lesson plan and rubrics were very helpful for lecturers to manage Writing for General Communication classes. This preparatory activity provides opportunities for lecturers to observe the position of malaqbiq value in learning activities as well as to determine topics and types of assignments to students. Second, the development of malaqbiq value also provided great motivation for lecturers and students.

Based on the results of the questionnaire, the students showed motivation, good 
response and a positive attitude towards prayer activities before studying. Students also showed the motivation of writing without cheating of other friends, and that was proven by their writing during the Midterm Exams. Lastly, the implementation of malaqbiq value in this course is an update on the previous course. In the previous year, this course has not contained malaqbiq values in accordance with the vision-mission and learning achievements of the course. Developing teaching material is very urgent as an effort for up-dating the teaching and learning process and this research tried to reach it (Ahmed, 2017).

The results also showed that malaqbiq value is very potential to be used as a source of a character value. This finding is similar to the results of previous studies conducted by (Srimusdikawati, 2017). She found that the implementation of malaqbiq character value in language learning has a high feasibility test value. Furthermore, the results also showed that local values can not only be implemented implicitly in English learning steps, but can also be indicators of achievements, assessments and learning materials. The argument is slightly different from the findings of (Agustini et al, 2014) at SMPN 1 Singaraja.

Character building derived from local values becomes a demand to improve the moral quality of today's human beings (Chowdhury, 2016). Not only in Indonesia, but character building has also been a major concern in developed countries such as Japan and the U.S.A. Even the rapid progress of the two countries is influenced by the character of their societies. On the other hand, Indonesia is experiencing a very big national problem that is disunity. Of course, this will not happen if Indonesian people have cultural relativism or mutual respect. The second character issue is the loss of manners of the young generation including students in terms of writing messages to their lecturers. STAIN Majene also have the same problem. Not only the language structure used, but students also do not pay attention to the context, topic and who the interlocutor is. This fact showed that students were unaware that written communication as part of their academic activities through both short messages and electronic mail is crucial and sensitive. Whereas, students are asked to master academic literacy to support their academic life (Defazio, et.al., 2010). Here are the observations about the short message written by English Education students:

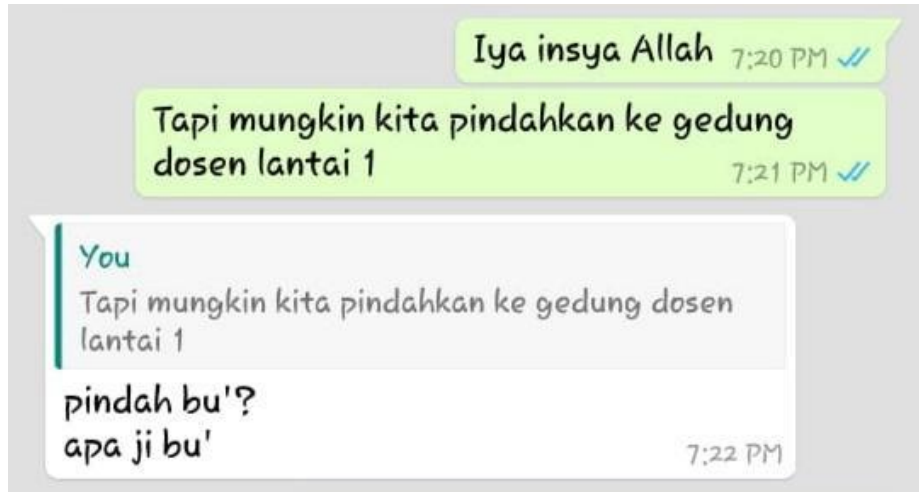

In this Writing for General Communication course, students were first taught about the implementation of malaqbiq values related to how to compose words and sentences well (mapia turang loa) as well as manners (mapia ampe) in an early meeting. The practice of writing messages was conducted later at the sixth and seventh meetings.

The third issue was that the practice of plagiarism was commonly committed by students. In the introductory session at the first meeting, students were asked if they had ever 
copied paste, and all answered yes/ever. Then after being taught about the concept of to tammarappa atonang (people who do not deprive others of their rights) and plagiarism is part of the theft, students showed improvement in their mid-term assignments and exams. The results of this study showed that the local value of malaqbiq could be used as a source of character education that could change students for the better (Agung, 2011). This was proven by student's high scores in the aspect of writing which was personal work (originality); 98.75. The results of the questionnaire also showed that there was a change in students' attitude where they felt relieve in learning and were aware that their character became better.

Lastly, the value of malaqbiq had the potential to be integrated with Islamic values in learning. Historically, the values embraced by Mandarese people have always relied on Islamic values (Idham \& Saprillah, 2013). It is also supported by expert statements stating that there are four sources of value developed in the education of the character of the Indonesian nation, among others religion, Pancasila, culture and educational purposes (Sudrajat, 2011). It turns out that malaqbiq also regulates the relationship between humans and God (To marakke in Puang). This value was exemplified when the classes were started by reading prayers and short surahs in an effort to ask for blessings and smoothness in studying.

\section{CONCLUSION}

Based on the research findings, the researchers conclude that the implementation of malaqbiq local value on the Writing for General Communication course at STAIN Majene is proven to be effective in building a positive attitude to fight against plagiarism. It was proven by the high score for originality they earned for their Mid-term test. Besides, this value also triggers their awareness to take context such as when and where into account when writing to other people especially to their lecturers. By implementing malaqbiq local value, they do not only strive to become better writers but also thrive to become better people.

\section{BIBLIOGRAPHY}

Agung, Leo. (2011). Character Education Integration in Social Studies Learning. Historia: International Journal of History Education, 12(2), 392-404. https://doi.org/10.17509/historia.v12i2.12111.

Ahmed, Shameem. (2017). Authentic ELT Materials in the Language Classroom: An Overview. Journal of Applied Linguistics and Language Research, 4(2), 181-202. https://www.jallr.com/index.php/JALLR/article/view/551

Ali, Sheeraz., et.al. (2015). The Importance of Culture in Second and Foreign Language Learning. Dinamika Ilmu, 15(1), 1-10. http://dx.doi.org/10.21093/di.v15i1.99.

Bahadori M, \& Hoseinpourfard M. (2012). Plagiarism: Concepts, Factors and Solutions. Iranian Journal of Military Medicine, 14(3), 168-177. Google Scholar

Birowo, Mario Antonius., \& Darmasturi, Rini. (2015). Media Literacy Strategy for 
Teenagers Based on Local Wisdom of Yogyakarta. Presented at the International Conference on "Communication/Culture and the Sustainable Development Goals (CCSDG): Challenges for a New Generation, Thailand, 2015.

Chowdhory, Mohammad. (2016). Emphasizing Morals, Values, Ethics, and Character Education in Science Education and Science Teaching. MOJES: The Malaysian Online Journal of Educational Education, 4(2), Google Scholar

D.A.E. Agustini dkk, (2014). Implemetasi Nilai-Nilai Karakter dalam Pembelajaran Bahasa Inggris. Jurnal Pendidikan dan Pengajaran, 47(2-3). Google Scholar

Defazio, Joseph., et.al. (2010). Academic Literacy: The Importance and Impact of Writing across the Curriculum - A Case Study. Journal of the Scholarship of Teaching and Learning, 10(2), 34-47. Google Scholar

Fatimah, F., \& Wulandari, I. (2018). Perception of Plagiarism among Students of Higher Education in Indonesia. Alphabet, 1(1), 30-40. https://doi.org/10.21776/ub.alphabet.2018.01.01.04

H. Silver. (2004). Evaluation Research in Education. University of Plymouth. (Online) http://www.edu.plymouth.ack.uk/resined/ evaluation/index.htm

Idham \& Saprillah. (2013). Malaqbiq: Identitas Orang Mandar. Yogyakarta: Arti Bumi Intaran.

Imroatus, S. (2016). Pengembangan Model Kurikulum Pendidikan Bahasa Inggris Berbasis KKNI. Jurnal Konstruktivisme, 8(1), 20-36. https://doi.org/10.35457/konstruk.v8i1.2

Rahman, Darmawan Masud. (1988). Puang dan Daeng: Kajian Sistem Nilai Budaya Orang Balanipa Mandar. Ujungpandang: Unversitas Hasanuddin (Disertasi)

Sari, Andika Puspita \& Setiawan, Ananda. (2018). The Development of InternetBased Economic Learing Media Using Moodle Approach. International Journal of Active Learning, 3(2), 100-109. https://doi.org/10.15294/ijal.v3i2.13449

Srimusdikawati. (2017). Pengembangan Bahan Ajar Bahasa dan Sastra Mandar Berbasis Karakter Malaqbiq di Sekolah Dasar Kabupaten Polewali Mandar. Universitas Negeri Makassar: Disertasi.

Sudrajat, Ajat. (2011). Mengapa Pendidikan Karakter? Jurnal Pendidikan Karakter, 1(1), 47-59. https://doi.org/10.21831/jpk.v1i1.1316

Watcharapunyawong, S., \& Usaha, S. (2013). Thai EFL students' writing errors in different text types: The interference of the first language. English Language Teaching, 6(1), 67-78. https://doi.org/10.5539/elt.v6n1p67 